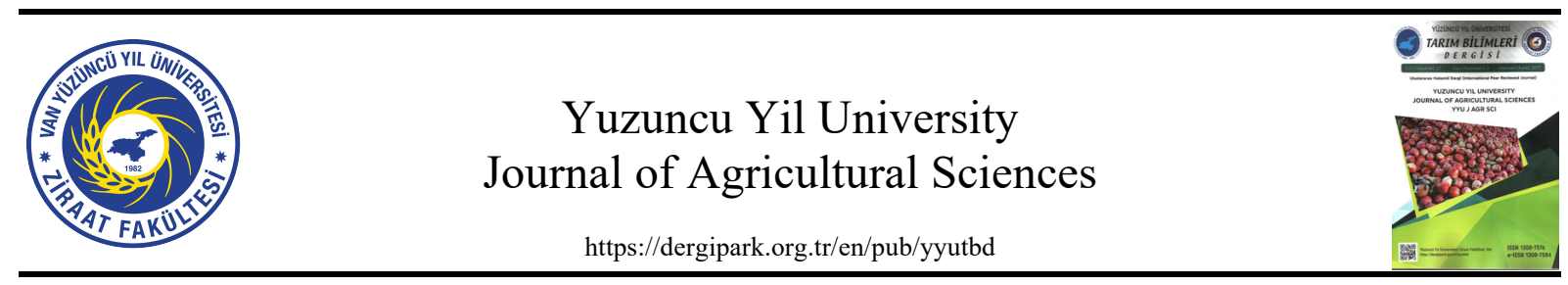

Research Article

\title{
Assessing Yield and Silage Quality of Intercropped Corn and Soybean in Different Planting Patterns and in Mardin Ecological Condition
}

\author{
Erdal HOMAN ${ }^{1}$, Şeyda ZORER ÇELEBi் ${ }^{2}$, Sibel ERDOĞAN ${ }^{* 3}$ \\ ${ }^{1}$ Van Yuzuncu Yil University, Institute of Natural and Applied Science M.Sc, Van, Turkey \\ ${ }^{2}$ Van Yuzuncu Yil University, Agriculture Faculty, Field Crops Department, 65080, Van, Turkey \\ ${ }^{3}$ Van Yuzuncu Yil University, Agriculture Faculty, Animal Science Department, 65080, Van, Turkey \\ ${ }^{1}$ https://orcid.org/0000-0001-5763-4643 ${ }^{2}$ https://orcid.org/0000-0003-1278-1994 ${ }^{3}$ https://orcid.org/0000-0003-2640-3871 \\ *Corresponding author e-mail: serdogan@yyu.edu.tr
}

\section{Article Info}

Received: 21.04 .2021

Accepted: 26.08 .2021

Online Published: 15.12 .2021

DOI: $10.29133 /$ yyutbd. 923261

Keywords

Corn,

Planting ratio,

Silage quality,

Soybean,

Yield.

\begin{abstract}
This study was carried out to determine the effect of silage on fermentation quality. The silage was produced by forage yield of mixed planting of corn and soybeans which was planted as a second crop in Mardin ecological conditions. The field experiment was carried out in a Randomized Complete Experiment Design with three replications at 7 different planting ratios [corn (C), $70 \%$ corn $+30 \%$ soybean $(70 \mathrm{C} 30 \mathrm{~S}), 60 \%$ corn $+40 \%$ soybean $(60 \mathrm{C} 40 \mathrm{~S}), 50 \%$ corn $+50 \%$ soybean $(50 \mathrm{C} 50 \mathrm{~S}), 40 \%$ corn $+\% 60$ soybean (40C60S), $30 \%$ corn + $70 \%$ soybean (30C70S) and soybean (S)]. The single (pure) and mixed yield obtained from each plot were left to fermentation in glass jars for 90 days in four repetitions. According to the results of the study, the highest fresh biomass obtained was 71071 and $68333 \mathrm{~kg} \mathrm{ha}^{-1}$ respectively from $60 \mathrm{C} 40 \mathrm{~S}$ and $70 \mathrm{C} 30 \mathrm{~S}$ mixtures, and the highest crude protein yield was obtained from $60 \mathrm{C} 40 \mathrm{~S}, 70 \mathrm{C} 30 \mathrm{~S}, 30 \mathrm{C} 70 \mathrm{~S}$ and $50 \mathrm{C} 50 \mathrm{~S}$ mixtures planting ratios. As the soybean ratio in the mixture increased, the $\mathrm{CP}$ ratio, silage $\mathrm{pH}$ and butyric acid (BA) concentration increased. While the lactic acid (LA) concentration of corn silage was the highest value with $2.67 \%$ in dry matter (DM), this value has been determined as $1.04 \%$ in soybean silage. To conclude, in regions having ecological conditions of Mardin province, it is recommended to mix planting with $30 \%$ or $40 \%$ ratio of soybean plant with corn plant to increase the protein value of corn silage and improve the fermentation of soybean.
\end{abstract}

\section{Mardin Ekolojik Koşullarında Farklı Karıșım Oranlarıyla Ekilen Mısır ve Soya Bitkisinin Yem Verimi ve Silaj Kalite Endeksleri}

\section{Makale Bilgileri}

Geliş: 21.04.2021

Kabul: 26.08.2021

Online Yayınlanma: 15.12.2021

DOI: 10.29133/yyutbd. 923261

\section{Anahtar Kelimeler}

Ekim oranı,

Misir,

Silaj kalitesi,

Soya fasulyesi,
Öz: Bu çalışma, Mardin ekolojik koşullarında ikinci ürün olarak ekimi yapılan mısır ve soya karışık ekimlerin kaba yem verimi ile oluşturulan silajların fermantasyon kalitesi üzerindeki etkisini belirlemek amacıyla yapılmıştır. Tarla denemesi 7 farklı ekim oranında [misir (M), \% 70 misir $+\% 30$ soya (70M30S), $\%$ $60 \mathrm{misir}+\% 40$ soya $(60 \mathrm{M} 40 \mathrm{~S}), \% 50 \mathrm{misir}+\% 50$ soya $(50 \mathrm{M} 50 \mathrm{~S}), \% 40 \mathrm{misir}+$ $\% 60$ soya (40M60S), $\% 30$ misir $+\% 70$ soya (30M70S) ve soya (S)] 3 tekrarlamal olarak tesadüf parselleri deneme desenine göre yürütülmüştür. Her bir parselden elde edilen yalın ve karışım hasıllar 4 tekrarlamalı olarak cam kavanozlarda 90 gün boyunca fermantasyona bırakılmışıtı. Araştırma sonuçlarına göre, en yüksek yeşil ot verimi 60M40S ve 70M30S karışık ekim oranlarından sırasıyla 71071 ve 68333 $\mathrm{kg} / \mathrm{ha}$ olarak, en yüksek ham protein verimi ise $60 \mathrm{M} 40 \mathrm{~S}, 70 \mathrm{M} 30 \mathrm{~S}, 30 \mathrm{M} 70 \mathrm{~S}$ ve 50M50S karışık ekim oranlarından elde edilmiştir. Karışımdaki soya fasulyesi 

artmıştır. Mısır silajının laktik asit konsantrasyonu KM'de \% 2.67 ile en yüksek iken bu değer soya silajında \% 1.04 olarak en düşük düzeyde belirlenmiştir. Sonuç olarak; Mardin İli ekolojik koşullarına sahip alanlarda mısır silajının protein değerini artırmak ve soyanın fermantasyonunu iyileştirmek için mısıra ek olarak \% 30 veya \% 40 oranında soya ile karışık ekimin yapılması önerilebilir.

\section{Introduction}

One of the crucial problems of animal breeding in Turkey is the inability to produce a sufficient amount of quality roughage. Natural meadows and pastures, which are one of the sources from which quality roughage is produced, have lost their yield power (yield capacity) due to the early and excessive grazing for many years. Increasing forage production in enterprises and popularizing silage-making techniques are the first solutions specifically to reduce the pressure on meadow pastures.

Roughages with a high-water ratio have a special effect on dairy cattle breeding enterprises. However, after harvesting, it all should be consumed in a short time. For this reason, in order to use the feed for a long time without spoiling, the feed must be either dried or ensiled. Said drying or ensiling is one of the commonly used storage forms for forages with high water content (Bilgen et al., 2005).

Corn is one of the most used plants in silage making due to its easy fermentation feature by dint of to its high content of water-soluble carbohydrates. It is the most widely used by farmers in Turkey, representing more than $80 \%$ of overall silage production in the country. Crop characteristics at harvesting, such as DM, water-soluble carbohydrate content, and buffering capacity are the main factors that can influence silage fermentation. The values of these characters have made the corn plant ideal for silage making. The deficiency of crude protein was considered the main disadvantage of corn silage (Koç et al., 1999).

The best treatment to increase the protein value of the silage is the ensiled corn in a mixture with plant materials with high protein content such as legumes. Soybean contains high levels of protein, vitamins, and minerals. Therefore, soybean is an important legume plant used as human food; it is also used as soybean leaves and stems can be grazed, ensiled, or dried to make hay. In Turkey, soybean planting for roughage is not very common. It is produced in a very small amount in the Mediterranean and Aegean regions in the form of mixed planting with corn in order to produce green forage and silage material (Tans1, 1987). Soybean silage contains an average of $18.3 \%$ crude protein (CP), 35\% DM, 43.3\% neutral detergent fiber (NDF), 32.3\% acid detergent fiber (ADF), 6.7\% acid detergent lignin (ADL). Although soybeans contain higher amounts of protein than many other types of feed, the natural fermentation of soybeans generally has low silage quality, resulting in an unpleasant odor and high BA concentration (Budakii, 2016). For soybean forage, a lower $\mathrm{pH}$ is needed to prevent undesirable bacteria growth. This means more sugar must be available for conversion to acid. Soybean has a natural buffering capacity and require more acid to reach a low $\mathrm{pH}$ than corn. The combination of low sugar content at harvest and high buffering capacity means soybean is especially prone to incomplete fermentation (Ni et al., 2018). The water-soluble carbohydrate content can be supplemented with sugar-rich (e.g. molasses) or forages such as corn, sorghum-sudangrass, which does not only improve the silage quality but also partially reduces the content of the cell wall component (Thompson et al., 2005). Besides, due to the problems caused by the use of single soybean silage, mixtures silage of soybean and corn can be successfully used in animal feeding (Ayaşan, 2011). The aim of this study was to determine the best mixture ratio to obtain the highest yield and best fermentation quality. This aim was achieved using planting soybean, which is a protein-rich legume plant, with a corn plant in different ratios under the conditions of Mardin Province.

\section{Material and Methods}

The experiment was carried out in Yeşilli District of Mardin Province of Turkey (Coordinates: $37^{\circ} 24^{\prime} 69.33^{\prime \prime} \mathrm{N}, 40^{\circ} 80^{\prime} 67.42^{\prime \prime} \mathrm{E}$ ) as a second crop after harvesting wheat in June 2015. Soybean variety Yemsoy and corn variety LG ADV 2898 were used as plant material in the experiment. Soybean variety Yemsoy (Glycine max L. Merr.) was a variety registered as silage in the fifth (V) maturation group by the Eastern Mediterranean Agricultural Research Institute. LG ADV 2898 corn variety is mid-late, the 
Single hybrid registered by Lima Grain Seed Breeding and Production Industry Trade Corporation, originating in France.

The climate data for the months in which the experiment was carried out in the Province of Mardin and the average for long years are shown in Table 1. The physical and chemical properties examined in the soil sample taken from the experiment field at a depth of 0-30 cm before the experiment are given in Table 2.

Table 1. Some climatic data of Mardin Province for the experiment site of the year (2015) and the average of long years ${ }^{1}$

\begin{tabular}{lcccccc}
\hline \multirow{2}{*}{ Months } & \multicolumn{2}{c}{ Median Temperature $\left({ }^{\circ} \mathbf{C}\right)$} & \multicolumn{2}{c}{ Relative Humidity (\%) } & \multicolumn{2}{c}{ Total Rainfall $(\mathbf{m m})$} \\
\cline { 2 - 7 } & $\mathrm{UYO}^{2}$ & 2015 & UYO & 2015 & UYO & 2015 \\
\hline June & 25.6 & 26.2 & 34 & 27.7 & 4.7 & 3.7 \\
July & 29.9 & 31.6 & 28 & 18.8 & 1.3 & 0.0 \\
August & 29.6 & 30.8 & 30 & 25.7 & 0.3 & 0.0 \\
September & 25.1 & 28.3 & 33 & 22.7 & 2.3 & 0.3 \\
October & 18.3 & 19.4 & 46 & 49.8 & 32.6 & 55.3 \\
Total & 128.5 & 136.3 & 171 & 144.7 & 41.2 & 59.3 \\
Average & 25.7 & 27.26 & 48 & 28.94 & 8.24 & 11.86 \\
\hline
\end{tabular}

${ }^{1}$ UYO, data the Directorate Meteorology Station in Mardin during the period 1950-2014.

${ }^{2}$ MGM records.

Table 2. Physical and chemical properties of the soils of the experiment site

\begin{tabular}{ccccccccc}
\hline Depth $(\mathrm{cm})$ & $\begin{array}{c}\text { Texture } \\
\text { Classe }\end{array}$ & $\begin{array}{c}\text { Salt } \\
(\%)\end{array}$ & $\begin{array}{c}\text { Phosphorus } \\
(\mathrm{ppm})\end{array}$ & $\begin{array}{c}\text { Potassium } \\
(\mathrm{ppm})\end{array}$ & $\begin{array}{c}\text { Organic } \\
\text { Matter }(\%)\end{array}$ & $\begin{array}{c}\mathrm{CaCo}_{3} \\
(\%)\end{array}$ & $\mathrm{pH}$ & Saturation \\
\hline $0-30$ & Clay loam & 0.02 & 3.8 & 159.8 & 1.6 & 27 & 7.6 & 56.1 \\
\hline
\end{tabular}

The field experiment was carried out in a Randomized Complete Experiment Design with three replications and it consisted of 21 plots, individual plot area was $14.75 \mathrm{~m}^{2}$. Corn and soybean varieties were planted in form of a single (pure) and mixed planting after harvesting wheat, taking into account the sowing norm of $50 \mathrm{~kg} / \mathrm{ha}$ of corn and $80 \mathrm{~kg} / \mathrm{ha}$ of soybeans. Planting ratios were determined according to the following; pure corn, $70 \%$ corn $+30 \%$ soybean, $60 \%$ corn $+40 \%$ soybean, $50 \%$ corn $+50 \%$ soybean, $40 \%$ corn $+60 \%$ soybean, $30 \%$ corn $+70 \%$ soybean, pure soybean. The sowing was done after the main crop wheat was harvested in June. While $70 \mathrm{~cm}$ between rows were used in pure plantings, soybean was planted $15 \mathrm{~cm}$ next to the main row of maize in mixed plantings. With the planting, $70 \mathrm{~kg}$ /ha pure phosphorus (Diammonium Phosphate) was used (Güneş et al., 1998). In single corn and mixed planting, when the corn became $30-40 \mathrm{~cm}$, ammonium sulfate fertilizer was added at a rate of $50 \mathrm{~kg} / \mathrm{ha}$ pure nitrogen in addition. Nitrogen fertilizer was not added to single soybean planting. After the last fertilization, weeds removal and covering roots with soil were carried out. The harvest stage of forages was done according to the dough period of corn. Corn and soybean In the field experiment of the study; plant height, green herbage yield, hay yield, and protein ratios were determined. In order to calculate the hay yield, samples of $500 \mathrm{~g}$ were dried in the oven at $70^{\circ} \mathrm{C}$ until they reached a constant weight. CP analysis was conducted in Dumatherm Manager $\mathrm{V}_{2} .05$ devices.

The mixtures of corn-soybean and corn, soybean were squeezed well into glass jars of $90.3 \mathrm{~mm}$ diameter and $141.1 \mathrm{~mm}$ height and left to fermentation for 90 days. For determination of $\mathrm{pH}$ and organic acid, $25 \mathrm{~g}$ of silage samples were homogenized in $100 \mathrm{~mL}$ distilled water followed by filtering with 0.22 $\mu \mathrm{m}$ membrane filters. Then, $100 \mathrm{~mL}$ was used to determine $\mathrm{pH}$ using a digital $\mathrm{pH}$ meter. The organic acid content was measured by high-performance liquid chromatography using a $7.7 \mathrm{~mm} \times 300 \mathrm{~mm} \mathrm{Hi}-$ Plex H column (Agillent) at $50^{\circ} \mathrm{C}$ with a mobile phase of $0.005 \mathrm{M} \mathrm{H}_{2} \mathrm{SO}$, a flow rate of $0.6 \mathrm{~mL} / \mathrm{min}$, an injection volume of $1 \mu \mathrm{l}$, and an UV detector $(210 \mathrm{~nm})(\mathrm{Ni}$ et al., 2017). The $\mathrm{CP}$, crude ash (CA) and ether extract (EE) were measured according to the standard procedures of the Association of Official 
Analytical Chemists (AOAC, 1990). The content of NDF and ADF was detected as described by Van Soest et al. (1991).

One-way analysis of variance (ANOVA) and Duncan multiple comparison test was used for statistical evaluation of the data related to the calculated yield parameters and silage fermentation quality of corn, soybean and corn-soybean mixtures according to the complete randomized experimental design (ANOVA). SPSS package program (IBM SPSS v23.0) was used in the statistical analysis of the data (SPSS, 2015).

\section{Results and Discussion}

\subsection{Evaluation soybean and corn planted yield and quality with different mixture ratios}

In the evaluation of the yield and quality of soybean and corn planted with different mixture ratios, it was found that the difference among plant height, green herbage yield, hay yield, CP ratio, and yield were significant $(\mathrm{p}<0.05)$. The highest plant height was obtained from single corn planting with $205.8 \mathrm{~cm}$, while the lowest plant height was recorded in single soybean planting with $134.8 \mathrm{~cm}$. On the other hand, the highest biomass yield was obtained by 71071 and $68333 \mathrm{~kg} \mathrm{ha}^{-1}$ from $60 \mathrm{C} 40 \mathrm{~S}$ and $70 \mathrm{C} 30 \mathrm{~S}$ mixtures respectively. The lowest biomass was found as $32857 \mathrm{~kg} \mathrm{ha}^{-1}$ in the pure soybean planting treatment $(\mathrm{p}<0.05)$. The highest DM was $22473 \mathrm{~kg} / \mathrm{ha}$ and $21228 \mathrm{~kg} \mathrm{ha}^{-1}$ for $60 \mathrm{C} 40 \mathrm{~S}$ and $70 \mathrm{C} 30 \mathrm{~S}$ mixed soybean planting ratios, the lowest hay yield by $9713 \mathrm{~kg} \mathrm{ha}^{-1}$ was determined in the treatment of pure soybean planting. While CP varied between $7.93-13.05 \%$, the highest $\mathrm{CP}$ according to the averages were found in single soybean planting with $13.05 \%$, and the lowest $\mathrm{CP}$ was detected in single corn planting by $7.9 \%$. According to the results of the study, CP yield was between $1273 \mathrm{~kg} \mathrm{ha}$ ${ }^{1}$ and $198.4 \mathrm{~kg} \mathrm{ha}^{-1}$. As recorded the highest $\mathrm{CP}$ yield in mixed planting treatments 60C40S, 70C30S, $30 \mathrm{C} 70 \mathrm{~S}$, and 50C50S have the same statistical group in terms of CP yield. The lowest CP yield was found in planting treatments S, 40C60S, and C (Table 3).

Table 3. Yield and quality criteria of corn, soybean, and corn-soybean intercropping systems in different ratios

\begin{tabular}{llllll}
\hline $\begin{array}{l}\text { Mixture } \\
\text { Ratios }\end{array}$ & $\begin{array}{l}\text { Plant Height } \\
(\mathrm{cm})\end{array}$ & $\begin{array}{l}\text { Biomass yield } \\
\left(\mathrm{kg} \mathrm{h}^{-1}\right)\end{array}$ & DM yield $\left(\mathrm{kg} \mathrm{ha}^{-1}\right)$ & $\mathrm{CP}(\%)$ & $\begin{array}{l}\text { CP Yield } \\
\left.\mathrm{d}(\mathrm{kg} \mathrm{ha})^{-1}\right)\end{array}$ \\
\hline $\mathrm{C}$ & $205.8 \pm 3.79^{\mathrm{a}}$ & $53929 \pm 351.74^{\mathrm{bc}}$ & $16848 \pm 130.42^{\mathrm{bc}}$ & $7.93 \pm 0.09^{\mathrm{e}}$ & $1335 \pm 9.06^{\mathrm{bc}}$ \\
$70 \mathrm{C} 30 \mathrm{~S}$ & $171.7 \pm 4.39^{\mathrm{b}}$ & $68333 \pm 97.44^{\mathrm{ab}}$ & $21228 \pm 41.68^{\mathrm{ab}}$ & $8.43 \pm 0.01^{\mathrm{de}}$ & $1790 \pm 3.75^{\mathrm{a}}$ \\
60C40S & $166.4 \pm 5.61^{\mathrm{b}}$ & $71071 \pm 635.21^{\mathrm{a}}$ & $22473 \pm 233.82^{\mathrm{a}}$ & $8.87 \pm 0.20^{\mathrm{cd}}$ & $1984 \pm 16.60^{\mathrm{a}}$ \\
50C50S & $165.5 \pm 3.79^{\mathrm{b}}$ & $54643 \pm 250.00^{\mathrm{bc}}$ & $16724 \pm 68.84^{\mathrm{bc}}$ & $9.26 \pm 0.23^{\mathrm{c}}$ & $1546 \pm 4.78^{\mathrm{ab}}$ \\
$40 \mathrm{C} 60 \mathrm{~S}$ & $164.0 \pm 1.43^{\mathrm{b}}$ & $45714 \pm 721.69^{\mathrm{cd}}$ & $13964 \pm 247.08^{\mathrm{cd}}$ & $9.36 \pm 0.31^{\mathrm{c}}$ & $1292 \pm 18.24^{\mathrm{bc}}$ \\
$30 \mathrm{C} 70 \mathrm{~S}$ & $169.7 \pm 3.82^{\mathrm{b}}$ & $53832 \pm 666.85^{\mathrm{bc}}$ & $16344 \pm 216.40^{\mathrm{bc}}$ & $10.67 \pm 0.06^{\mathrm{b}}$ & $1743 \pm 22.57^{\mathrm{ab}}$ \\
S & $134.8 \pm 3.33^{\mathrm{c}}$ & $32857 \pm 327.33^{\mathrm{d}}$ & $971.3 \pm 90.50^{\mathrm{d}}$ & $13.05 \pm 0.33^{\mathrm{a}}$ & $1273 \pm 14.72^{\mathrm{c}}$ \\
\hline F- value & $25.354^{* *}$ & $7.326^{* *}$ & $7.180^{* *}$ & $59.546^{* *}$ & $4.177^{*}$ \\
\hline
\end{tabular}

a, b, c, d, e: The difference between values with different letters in the same column is significant $(\mathrm{P}<0.05)$. C: Corn; $70 \mathrm{C} 30 \mathrm{~S}: 70 \%$ corn $+30 \%$ soybean; 60C40S: $60 \%$ corn $+40 \%$ soybean; $50 \mathrm{C} 50 \mathrm{~S}$ : $50 \%$ corn $+50 \%$ soybean, $40 \mathrm{C} 60 \mathrm{~S}$ : $40 \%$ corn $+\% 60$ soybean; $30 \mathrm{C} 70 \mathrm{~S}$ : $30 \%$ corn $+70 \%$ soybean; S: Soybean.

It is stated that the plant height, biomass, and DM is higher in the sole corn compared to cornsoybean intercropping treatments, and whereas the $\mathrm{CP}$ yield increased in the corn-soybean intercropping treatment (Marinov and Marinova, 1967; Kalaidzhieva, 1970; Petrakieva, 1975; Beets, 1977; Alaca and Ozaaslan Parlak, 2017). Despite the decreased weight in a mixed planting, significant increases were provided in terms of the protein content of the feed. As a matter of fact, due to the low protein value of corn silage, it is necessary to add additional nutrients to the ratio (Yücel et al., 2009). For this reason, the silage products obtained by the intercropping of Leguminosae and Gramineae will be able to meet additional feed requirements. Erdoğdu et al. (2013) and Alaca and Ozaslan Parlak (2017) concluded that $\mathrm{CP}$ yield of plants in the intercropping system was increased as compared with those for monocropping soybean. Ayaşan (2011) stated that intercropping treatment of 1 corn +1 soybean or 1 corn +2 soybean in alternative rows or mixing soybean and corn in certain proportions during ensiled is a great benefit in increasing the quality of silage. 


\subsection{Chemical composition and silage fermentation characteristics of corn and soybean intercropping systems}

The chemical composition of silage groups is showed in Table 4. There were differences between the treatment groups in terms of DM, CA, CP, EE, NDF, and ADF content $(\mathrm{p}<0.01)$. In terms of DM contents, all the silages in the study showed values between $26.54-29.25 \%$, and the lowest DM content was registered in the S silage group $(\mathrm{p}<0.05)$. One of the most important features of a crop to be ensiled is the appropriate DM content during the harvest stage. The most important factors influencing the DM content are the stage of maturity at the time of harvest and the wilted forage before ensiling. Vargas-Bella-Perez et al. (2008) determined the DM content of ensiled soybean silage that they harvested at the full capsule stage as $40.9 \%$. Ni et al. (2017) found that the DM content of soybean silage ranged from $24.86 \%$ to $27.22 \%$. Erdal et al. (2016) reported that the DM content of soybean silage was $22.18 \%$ and increased to $25.23 \%$ with the increase in the ratio of corn in the mixture. The results showed that soybean silage had the highest value of CA. This value decreased as the percentage of corn in the mixture of silage decreased $(\mathrm{p}<0.05)$. Karakozak et al. (2010) reported that the CA content of corn, soybean, and corn-soybean mixture silage was between $12.19-19.13 \%$, the highest value CA content was $19.13 \%$ of the pure $(100 \%)$ soybean silage and the lowest value was $12.19 \%$ of the pure $(100 \%)$ corn silage. The different factors such as plant genotypes, planting density, harvest date, irrigation, and fertilization affected the nutrient content of silage (Vasco-Correa and Li, 2015). One of the intercropping objectives of corn and soybeans is to increase the $\mathrm{CP}$ content of the silage. The $\mathrm{CP}$ content of soybean silage was $15.56 \%$, and the $\mathrm{CP}$ content of the silage increased as in soybean ratio increased in the mixture $(p<0.05)$. Blaunt et al. (2006) reported that the soybean supplement did not only increase the CP level in corn silage but also improved the taste and energy level. Demirel et al. (2009) stated that a $20 \%$ or $30 \%$ soybean additive was required in addition to corn to increase the CP content in corn silage and to improve the fermentation of soybean. Although soybean protein is very important for silage quality, fiber concentration of silage is considered to be another important quality parameter of silage (Oba and Allen 1999; Kezar 2001). The NDF and ADF are the most active fiber components in silage (Van Soest et al., 1991; Wolfrum et al., 2009). While NDF content was determined the lowest in soybean silage $(38.68 \%)$ and the highest in corn silage $(48.90 \%)$, ADF content was determined the highest value $(33.23 \%)$ in soybean silage $(p<0.05)$. The quality of the roughages is primarily indicated by the amount and composition of their structural carbohydrate contents. NRC (2001) reported that dairy cattle rations should have a minimum value of $25 \%$ from NDF, $18.7 \%$ of it should come from roughage feed for rumination and rumen health. The NDF and ADF values were obtained in the study Erdal et al. (2016), Vargas-Bella-Perez et al. (2008), and Undersander et al. (2007) were in harmony with the values reported.

Fermentation quality criteria of silages are given in Table 5. The $\mathrm{pH}$ value of silage is an important parameter in defining the level of fermentation in the silo, and the ratio of decreasing in $\mathrm{pH}$ is considered an important indicator to reflect microbial activity and the silage fermentation process. The $\mathrm{pH}$ value of good quality silage is between 3.5 to 4.2 (Uygur, 2016; Ni et al., 2017). Accordingly, while the $\mathrm{pH}$ value of corn silage was 4.20 , this value was 4.94 for soybean silage $(\mathrm{p}<0.05)$. The low $\mathrm{pH}$ value in corn silage was due to the high content of easily soluble carbohydrates. On the other hand, soybeans have a high buffering feature due to the high protein content and low carbohydrate content, and the proteins neutralize the acids and prevent the $\mathrm{pH}$ from decreasing. In all mixed silages, $\mathrm{pH}$ values fell below 4.50. This is an indication that the silage is preserved with a low $\mathrm{pH}$, which encourages the production of sufficient LA. The LA, with strong acidity and a pKa of 3.86, is the main organic acid responsible for $\mathrm{pH}$ reduction. In this study, the LA concentration the highest concentration with $2.67 \%$ DM was recorded for corn silage, while the lowest concentration with $1.04 \%$ DM was recorded for soybean silage $(\mathrm{p}<0.05)$. Serbester et al. (2015) found that the $\mathrm{pH}$ of corn silage was 3.8, soybean silage was 5.5, and mixed silage was between 3.9 - 4.1. A similar study also found that the $\mathrm{pH}$ was 3.87 and the lactic acid was $2.45 \%$ in the silages prepared from a mixture of $40 \%$ corn $+60 \%$ soybean (Koç et al.,1999). Acetic acid (AA) is the acid found in the second-highest concentration in silage, usually ranging from 1 to $3 \%$ of DM, while BA should not be detectable in well-fermented silages (Kung et al., 2018). In a study conducted by Güre (2016), AA ratios in sweet millet, cowpea and $50 \%$ sweet millet + $50 \%$ cowpea silage were determined as $0.13 \%, 0.67 \%$, and $0.31 \%$, respectively, and reported that AA concentration increased with the increase of cowpea ratio in the mixture. The presence of BA indicates 
metabolic activity from clostridial organisms, which leads to large losses of DM and poor recovery of energy (Pahlow et al., 2003). In this study, the highest BA concentration was determined in soybean silage with $0.36 \%$ and the BA concentration decreased with the increase of the corn ratio in the mixture $(p<0.05)$. Besides the presence of BA, clostridial silages are often characterized by a higher-than-normal $\mathrm{pH}$ and higher than normal concentrations of ammonia nitrogen $\left(\mathrm{NH}_{3}-\mathrm{N}\right)$, and soluble protein (Kung et al., 2018). As shown in Table 5, the $\mathrm{NH}_{3}-\mathrm{N}$ content of soybean silage is $8.83 \%$ and this value indicates the $\mathrm{CP}$ degradation of soybeans and the increase in clostridial activity.

Table 4. Crude nutrient content of silages (\%)

\begin{tabular}{lllllll}
\hline Mixture Ratios & DM & CA & CP & EE & NDF & ADF \\
\hline C & $29.25 \pm 0.28^{\mathrm{a}}$ & $5.15 \pm 0.18^{\mathrm{c}}$ & $9.24 \pm 0.17^{\mathrm{e}}$ & $4.03 \pm 0.18^{\mathrm{b}}$ & $48.90 \pm 1.96^{\mathrm{a}}$ & $23.90 \pm 0.72^{\mathrm{d}}$ \\
$70 \mathrm{C} 30 \mathrm{~S}$ & $28.78 \pm 0.25^{\mathrm{ab}}$ & $5.46 \pm 0.08^{\mathrm{bc}}$ & $10.20 \pm 0.10^{\mathrm{d}}$ & $4.16 \pm 0.10^{\mathrm{b}}$ & $42.61 \pm 1.08^{\mathrm{bc}}$ & $27.66 \pm 0.25^{\mathrm{b}}$ \\
60C40S & $29.02 \pm 0.17^{\mathrm{a}}$ & $5.57 \pm 0.20^{\mathrm{bc}}$ & $10.52 \pm 0.17^{\mathrm{dd}}$ & $4.73 \pm 0.09^{\mathrm{a}}$ & $41.05 \pm 0.64^{\mathrm{cd}}$ & $23.28 \pm 0.53^{\mathrm{d}}$ \\
50C50S & $29.03 \pm 0.31^{\mathrm{a}}$ & $5.68 \pm 0.13^{\mathrm{bc}}$ & $10.28 \pm 0.11^{\mathrm{d}}$ & $3.86 \pm 0.20^{\mathrm{b}}$ & $41.24 \pm 0.52^{\mathrm{cd}}$ & $25.74 \pm 0.39^{\mathrm{c}}$ \\
$40 \mathrm{C} 60 \mathrm{~S}$ & $27.51 \pm 0.26^{\mathrm{bc}}$ & $5.77 \pm 0.19^{\mathrm{b}}$ & $10.81 \pm 0.13^{\mathrm{c}}$ & $3.86 \pm 0.04^{\mathrm{b}}$ & $44.73 \pm 0.55^{\mathrm{b}}$ & $25.61 \pm 0.21^{\mathrm{c}}$ \\
$30 \mathrm{C} 70 \mathrm{~S}$ & $28.03 \pm 0.16^{\mathrm{ab}}$ & $5.91 \pm 0.11^{\mathrm{b}}$ & $11.76 \pm 0.10^{\mathrm{b}}$ & $3.93 \pm 0.11^{\mathrm{b}}$ & $43.59 \pm 0.49^{\mathrm{bc}}$ & $28.77 \pm 0.35^{\mathrm{b}}$ \\
S & $26.54 \pm 0.23^{\mathrm{c}}$ & $8.61 \pm 0.16^{\mathrm{a}}$ & $15.56 \pm 0.21^{\mathrm{a}}$ & $4.22 \pm 0.06^{\mathrm{b}}$ & $38.68 \pm 0.38^{\mathrm{e}}$ & $33.23 \pm 0.37^{\mathrm{a}}$ \\
\hline F- value & $5.393^{* *}$ & $48.965^{* *}$ & $187.222^{* *}$ & $6.031^{* *}$ & $10.850^{* *}$ & $58.857^{* * *}$ \\
\hline
\end{tabular}

DM: Dry matter; CA: Crude ash; CP: Crude protein; EE: Ether extract; NDF: Neutral detergent fiber; ADF: Acid detergent fiber. $\mathrm{a}, \mathrm{b}, \mathrm{c}, \mathrm{d}$. The difference between values with different letters in the same column is significant $(\mathrm{P}<0.05) ;{ }^{*} \mathrm{P}<0.05,{ }^{* *} \mathrm{P}<0.01$.

Table 5. Fermentation criteria of silages (\% DM)

\begin{tabular}{lllllll}
\hline Mixture Ratios & $\mathrm{pH}$ & $\mathrm{NH}_{3}-\mathrm{N}$ & $\mathrm{LA}$ & $\mathrm{AA}$ & $\mathrm{PA}$ & $\mathrm{BA}$ \\
\hline $\mathrm{C}$ & $4.20 \pm 0.01^{\mathrm{e}}$ & $3.78 \pm 0.11^{\mathrm{d}}$ & $2.67 \pm 0.27^{\mathrm{a}}$ & $0.07 \pm 0.01^{\mathrm{d}}$ & $0.06 \pm 0.01^{\mathrm{e}}$ & $0.04 \pm 0.003^{\mathrm{d}}$ \\
70C30S & $4.25 \pm 0.01^{\mathrm{c}}$ & $4.55 \pm 0.09^{\mathrm{c}}$ & $2.29 \pm 0.09^{\mathrm{b}}$ & $0.19 \pm 0.01^{\mathrm{c}}$ & $0.49 \pm 0.02^{\mathrm{d}}$ & $0.18 \pm 0.01^{\mathrm{c}}$ \\
60C40S & $4.22 \pm 0.01^{\mathrm{de}}$ & $4.73 \pm 0.06^{\mathrm{c}}$ & $1.89 \pm 0.07^{\mathrm{c}}$ & $0.44 \pm 0.05^{\mathrm{a}}$ & $0.62 \pm 0.05^{\mathrm{d}}$ & $0.24 \pm 0.01^{\mathrm{b}}$ \\
50C50S & $4.24 \pm 0.01^{\mathrm{cd}}$ & $4.64 \pm 0.06^{\mathrm{c}}$ & $1.85 \pm 0.07^{\mathrm{c}}$ & $0.22 \pm 0.02^{\mathrm{c}}$ & $0.81 \pm 0.03^{\mathrm{c}}$ & $0.24 \pm 0.02^{\mathrm{b}}$ \\
40C60S & $4.26 \pm 0.01^{\mathrm{c}}$ & $4.73 \pm 0.11^{\mathrm{c}}$ & $1.33 \pm 0.07^{\mathrm{d}}$ & $0.31 \pm 0.04^{\mathrm{b}}$ & $1.04 \pm 0.08^{\mathrm{b}}$ & $0.24 \pm 0.02^{\mathrm{b}}$ \\
30C70S & $4.35 \pm 0.01^{\mathrm{b}}$ & $5.49 \pm 0.20^{\mathrm{b}}$ & $1.01 \pm 0.07^{\mathrm{d}}$ & $0.17 \pm 0.01^{\mathrm{c}}$ & $1.19 \pm 0.10^{\mathrm{b}}$ & $0.39 \pm 0.03^{\mathrm{a}}$ \\
$\mathrm{S}$ & $4.94 \pm 0.01^{\mathrm{a}}$ & $8.83 \pm 0.32^{\mathrm{a}}$ & $1.04 \pm 0.08^{\mathrm{d}}$ & $0.17 \pm 0.01^{\mathrm{c}}$ & $1.85 \pm 0.06^{\mathrm{a}}$ & $0.36 \pm 0.01^{\mathrm{a}}$ \\
\hline F- value & $812.888^{* *}$ & $108.189^{* *}$ & $27.647^{* *}$ & $21.416^{* *}$ & $108.371^{* *}$ & $44.557^{* *}$ \\
\hline
\end{tabular}

LA: Lactic acid; AA: Acetic acid; PA: Propionic acid; BA: Butyric acid.

a, b, c, d, e : The difference between values with different letters in the same column is significant $(\mathrm{P}<0.05) ;{ }^{*} \mathrm{P}<0.05,{ }^{* *} \mathrm{P}<0.01$.

\section{Conclusion}

This research was conducted in order to determine the effects of different intercropping patterns of corn with soybean on agronomic characters, forage yield, and silage quality in the ecological conditions of Mardin. In the study, it was determined that the mixtures had a higher yield than single plantings in terms of fresh biomass. The highest yield was obtained from the experimental plots 60C40S and $70 \mathrm{C} 30 \mathrm{~S}$ mixtures ratios. These mixture ratios gave the best crude protein yield compared to monocropping. Significant differences have been found in the silage fermentation characteristics results of silages of materials obtained from intercropping. The finding that reflects the microbial activity and silage fermentation in the silage material is the silage $\mathrm{pH}$, and the increase in the legume ratio caused increases in the $\mathrm{pH}$. Except for soybean silage, when $\mathrm{pH}$ and $\mathrm{NH}_{3}-\mathrm{N}$ concentrations were examined, the results showed that soybean silage encouraged sufficient lactic acid production, and the lower $\mathrm{pH}$ contributed to protecting silage. According to the results of silage fermentation properties examined, it is thought that increasing the rate of soybean by $50 \%$ in silage will not cause a significant change in silage quality. In conclusion, in the ecological conditions of Mardin province, it was considered that for intercropping of corn and soybean plants, $70 \%$ corn $+30 \%$ soybean and $60 \%$ corn $+40 \%$ soybean mixtures could be used as ideal mixtures in terms of biomass yield and silage quality. 


\section{Acknowledgements}

The authors gratefully acknowledge Van Yuzuncu Yil University Scientifc Researches Project Unit (Project No: 2015-FBE-YL279) for financial support.

\section{References}

AOAC. (1990). Official Methods of Analysis (15th Ed.). Maryland, USA: Association of Official Analytical Chemists.

Alaca, B., \& Ozaslan Parlak, A. (2017). The effect of maize and sorghum-sudangrass crosses intercropped with soybean, cowpea, guar on, silage yield and quality. COMU J Agric Fac, 5(1), 99-104.

Ayaşan, T. (2011). Soybean silage and usage of animal nutrition. J Fac Vet Med Univ Erciyes, 8(3), 193-200.

Beets, W. C. (1977). Multiple cropping of maize and soybeans under high level of crop management. Netherlands Journal of Agricultural Science, 25(2), 95-102.

Bilgen, H., Yalçın, H., Özkul, H., Çakmaz, B., Polat, M., \& Kılıç, A. (2005). Effects of packaging material color, vacuum application and storage conditions on the quality of packed corn silage. Journal of Agriculture Faculty of Ege University, 42(2), 77-85.

Blaunt, A. R. S., Wright, R. K., Sprenkel, T. D., Hewitt, T. D., \& Myer, R. O. (2006). Forage soybeans for grazing, hay and silage. https://edis.ifas.ufl.edu/pdffiles/AG/AG18400.pdf. Access date: 17.02.2021. Univ of Florida IFAS Extension, SS-AGR-180.

Budakii, C.E. (2016). Nutritive values of soybean silages ensiled with mazie at the different rates. Legumes Research, 39, 810-813.

Demirel, M., Çelik, S., Temur, C., Güney, M., \& Çelik, S. (2009). Determination of fermentation properties and digestiblity characteristics of combination of corn-soybean and corn silages. Journal of Animal and Veterinary Advances, 8(4), 711-714.

Erdal, S., Pamukçu, M., Çürek, M., Kocatürk, M., \& Yılmaz Doğu, Ö. (2016). Silage yield and quality of row intercropped maize and soybean in a crop rotation following winter wheat. Archives of Agronomy and Soil Science, 62(11), 1487-1495.

Erdoğdu, İ., Altınok S., \& Genç A. (2013). The effect of different seeding rates of intercropped corn an soybean on some plant characteristics and forage yield. Research Journal of Biology Sciences, 6(1), 06-10.

Güneş, A., Alpaslan, M., \& İnal A. (1998). Experimental Techniques, Ankara University Faculty of Agriculture Publications, Ankara.

Güre, E. (2016). An investigation on usage possibilities of sweet sorghum (Sorghum Bicolor (L.) Moench Var. Saccharatum) and black eyed-pea (Vigna Unguiculata (L.) Walp.) mixture for silage. (M.Sc). Ege University Institute of Natural and Applied Science, İzmir.

IBM Corp. Released (2015). IBM SPSS Statistics for Windows, Version 23.0. Armonk, NY: IBM Corp. Kalaidzhieva, S. (1970). Results of intercropping maize and soybeans. Herbage Abstracts, 40(4), 400.

Karakozak, E., \& Ayaşan, T. (2010). Effect of inoculant in silages in which different forage crops and their mixtures on flieg point and crude nutrient content. Journal of the Faculty of Veterinary Medicine, Kafkas University, 16(6), 987-994.

Kezar, W.W. (2001). Successful use of high quality corn silage for dairies in the western United States. Proceedings, 31st California Alfalfa and forage Symposium; 12-13 Dec 2001, California.

Koç, F., Özdüven, M. L., \& Yurtman, İ. Y. (1999). Effects of salt and microbial inoculants on the quality and aerobic stability of the maize-soybean silage. Journal of Animal Production, 39-40, 64-71.

Kung, J.L., Shaver, R.D., Grant, R.J., \& Schmidt, R.J. (2018). Silage review: Interpretation of chemical, microbial, and organoleptic components of silages. Journal of Dairy Science, 101(5), 4020-4033.

Marinov, M., \& Marinova, R. (1967). Maize and soybeans grown in a mixture for silage in the vidin area. Herbage Abstracts, 37(3), 175. 
Ni, K., Wang, F.F., Zhu, B., Yang, J., Zhou, G., Pan, Y., Tao, Y., \& Zhong, J. (2017). Effects of lactic acid bacteria and molasses additives on the microbial community and fermentation quality of soybean silage. Biosource Technology, 238,706-715.

Ni, K., Zhao, J., Zhu, B., Su, R., Pan, Y., Ma, M., Zhou, G., Tao, Y., Liu, X., \& Zhong, J. (2018). Assessing the fermentation quality and microbial community of the mixed silage of forage soybean with crop corn or sorghum. Biosource Technology, 265, 563-567.

NRC. (2001). Nutrient Requirements of Dairy Cattle (7th Rev. Ed.) Natl. Acad. Sci., Washington, DC

Oba, M., \& Allen, M.S. (1999). Evaluation of the importance of the digestibility of neutral detergent fiber from forage: Effects on dry matter intake and milk yield of dairy cows. Journal of Dairy Science. 82, 589-596.

Pahlow, G., Muck, R.E., Driehuis, F., Oude Elferink, S.J.W.H., \& Spoelstra, S.F. (2003). Microbiology of Ensiling. In D.R. Buxton, R.E. Muck, \& J.H. Harrison (Eds.) Silage Science and Technology (pp. 31-93), American Society of Agronomy, Madison, WI.

Petrakieva, I. (1975). The relationship between maize and soybean plants in mixed stands in relation the sowing method. Herbage Abstracts, 45(29), 65.

Serbester, U., Akkaya, M.R., Yucel, C., \& Gorgulu, M. (2015). Comparison of yield, nutritive value, and in vitro digestibility of monocrop and intercroped corn-soybean silages cut at two maturity stages. Italian Journal of Animal Science, 14, 66-70.

Undersander, D., Jarek, K., Anderson, T., Schneider, N., \& Milligan, L. (2007). A guide to making soybean silage. Forage and grazinglands, Plant management network. http://128.104.248.62/ces/ag/issues/drought/documents/SoybeanSilage.pdf Access date: 25.01.2021.

Uygur, A. M. (2016). Silaj kalitesinin fiziksel ve kimyasal yöntemlerle belirlenmesi http://arastirma.tarim.gov.tr/etae/Belgeler/EgitimBrosur/127-ciftcibro.pdf Access date: 14.07.2016.

Tans1, V., 1987. The effects on forage grain yields and quality characteristics of corn and soybean in various planting patterns as second crop in Çukurova (Phd.). Cukurova University Institute of Natural and Applied Science, Adana.

Van Soest, P. J., Robertson, J. B., \& Lewis, B. A. (1991). Methods for dietary fiber, neutral detergent fiber and nonstarch polysac-charides in relation to animal nutrition. Journal of Dairy Science, 74, 3583-3597.

Vargas-Bello-Perez, E., Mustafa, A. F., \& Seguin, P. (2008). Effects of feeding forage soybean silage on milk production, nutrient digestion, and ruminal fermentation of lactating dairy cows. Journal of Dairy Science, 91, 229-235.

Vasco-Correa, J., \& Li, Y. (2015). Solid-state anaerobic digestion of fungal pretreated Miscanthus sinensis harvested in two different seasons. BioSource Technology, 185, 211-217.

Wolfrum E.J., Lorenz, A. J., \& Leon, N. (2009). Correlating detergent fiber analysis and dietary fiber analysis data for corn stover collected by NIRS. Cellulose, 16, 577-585. 